moderately large, transverse, covering a large portion of the very short head, whitish, the areolæ very small.

Elytra moderately broad, broady rounded at the tips, pale testaceous, with broad fuscous band in front of the middle of costal area, most of the nervures of subcostal, discoidal and sutural areas (except apex) fuscous, the areolæ transparent; broadest at the transverse fascia; costal area broad, triseriate, the areolæ moderately large. Discoidal area elevated (with sutural area), short, not reaching the middle of the elytra, testaceous at the base and apex, the areolæ semi-opaque; subcostal area broad, composed of five rows of areolæ at its widest part, the areolæ small, subequal in size to those of discoidal area; sutural area with one very large cell near its apex.

Length, $2.45 \mathrm{~mm}$; width, $1.3 \mathrm{~mm}$.

Holotype, female, Mina Carlota, Trinidad Mts., March 24, 1925 , in writer's collection. L. unicarinata Champ., and $L$. myersi are very much unlike the type of the genus of Leptopharsa. The characters of the pronotum and the color of the elytra and paranota readily separate these species.

\title{
THE SYNONYMY OF ACTINA VIRIDIS (SAY).
}

\section{By Charles W. Johnson, Boston Society of Natural History}

For some time it has been evident that the old species, Beris viridis Say, was being subjected to rather reckless treatment. The description by Say is good, and the character "scutel with four yellow spines" has always readily separated it from the other species formerly referred to Beris. In 1848 Walker described Beris quadridentata. As the name indicates it would apply only to the male, having four yellow spines on the scutellum and not to the female with six spines. B. quadridentata was placed in the synonymy under $B$. viridis Say by Osten Sacken (Catl. p. 44, 1878).

Dr. G. Enderlein in 1920 (Mitt. Zool. Mus., Berlin, 10:209), 
recognized and redescribed $B$. quadridentata Walker, making it the type of a new genus Hemiberis, although in the same publication (page 192) he recognizes Actina viridis (Say). Dr. Enderlein's description of $H$. quadridentata (Walk.) is based on a single male from Wisconsin and agrees in every respect with the male of $A$. viridis. His generic conclusion was evidently made solely upon comparison with species of Hoplacantha Rond., Hemiberis in the male having the eyes separated and the posterior metatarsi thickened.

Under the title "The generic position of Beris viridis Say, "(Canadian Ent., vol. 56, p 24, 1924), Mr. C. H. Curran proposes a new genus Allactina, genotype Beris (Actina) viridis Say. In the generic diagnosis he says:- "scutellum with six large spines," a character which does not apply to B. viridis. There is also the following discrepancy in the comparison of genera,"In addition, the eyes of the male in this species are broadly separated, while they are contiguous in all the species I have seen of both Beris and Actina." Eyes of the male not contiguous is one of the leading characters that separates Actina from Beris. The above brings up a question. Should the name Allactina be applied to the genotype or to the species with six spines on the scutellum. As the intention was to propose a generic name for B. viridis, I am inclined to think that-"six large spines" was probably written by mistake.

Dr. O. A. Johannsen under "Beris quadridentata Walker" (Bull. Brooklyn Ent. Soc., XX, 214, 1925) says:-"In the British Museum there are several specimens under this name. Two specimens a male and a female, have been selected as the types. These, however, are not conspecific. The male is Beris viridis Say, having four scutellar spines, as indicated by the specific name, but the female specimen, also bearing a type label has six spines. The synonomy noted above as pointed out by Osten Sacken, makes the generic designation Allactina Curran, a synonym of Hemiberis Enderlein"

As to the genus Actina. With eight specimens of the genotype ( $A$. nitens Latr.) before me, I find no character of sufficient importance to separate $B$. viridis from this genus. The additional posterior vein from the discal cell in $A$. nitens is only 
rudimentary and is entirely absent in two specimens, while in two others the vein forming the outer part of the discal cell is wanting. It seems therefore apparent that the synonomy of this species should stand as follows:-

\section{Actina viridis (Say).}

Beris viridis Say, Long's Exped., App., 368, 1824.

Beris quadridentata Walker, List Dipt., I, 127, 1848.

Actina viridis Aldrich, Cat'l., 174, 1905

Hemiberis quadridentata Enderlein, Mitteilungen Zool. Mus. Berlin, 10: 209, 1920.

Allactina viridis Curran, Can. Ent., 56: 24, 1924.

The species is widely distributed. I have before me 65 specimens collected from Codroy, Newfoundland, to St. Paul, Minn., and south to the Black Mts., N. C. The only noticeable variation is in those from the more northern loca ities, especially in the males. Specimens from East Cape Anticosta Island, collected July 7, 1881 by Mr Samuel Henshaw, are slightly smaller and have the legs dark. All of the femora are brownishblack, only the extreme basal part of the tibiæ are yellow, the tarsi are also dark except the posterior metatarsi, which are also brownish toward the outer end. The female however, has only the tips of the femora, the outer two-thirds of the tibiæ and the tarsi (except the posterior metatarsi) dark brown. I propose the varietal name of obscuripes or the six specimens from Anticosta Island. Holytype and three paratypes in the Museum of Comparative Zoology. Allotype and one paratype in the Museum of the Boston Society of Natural History. Two males from Low Bush, Lake Abittibi, Ontario, June 11, 1925 (N. K. Bigelow), have the femora blackish, except for narrow basal and apical bands of yellow. A third male, however, from the same locality has the femora yellow. 

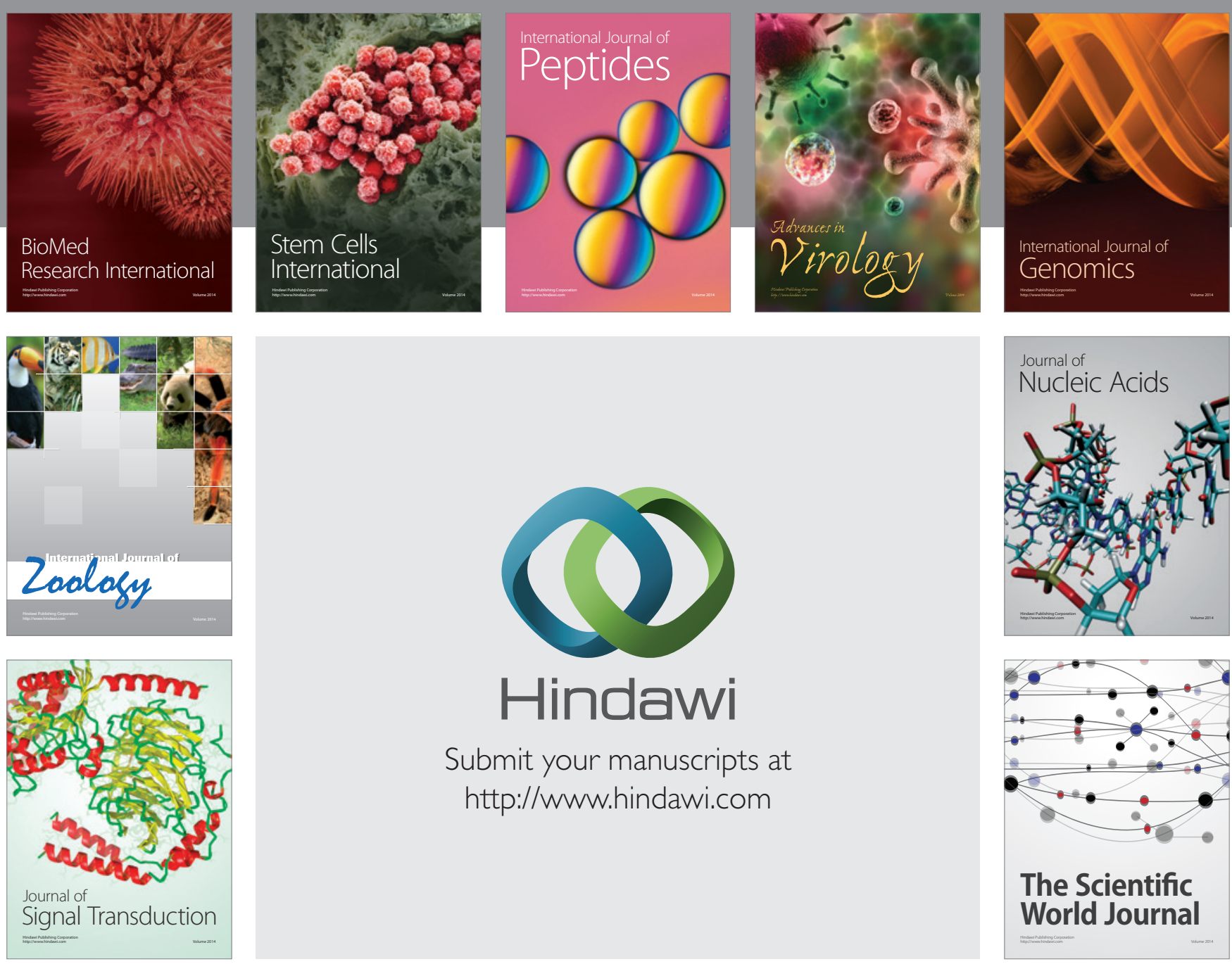

Submit your manuscripts at

http://www.hindawi.com
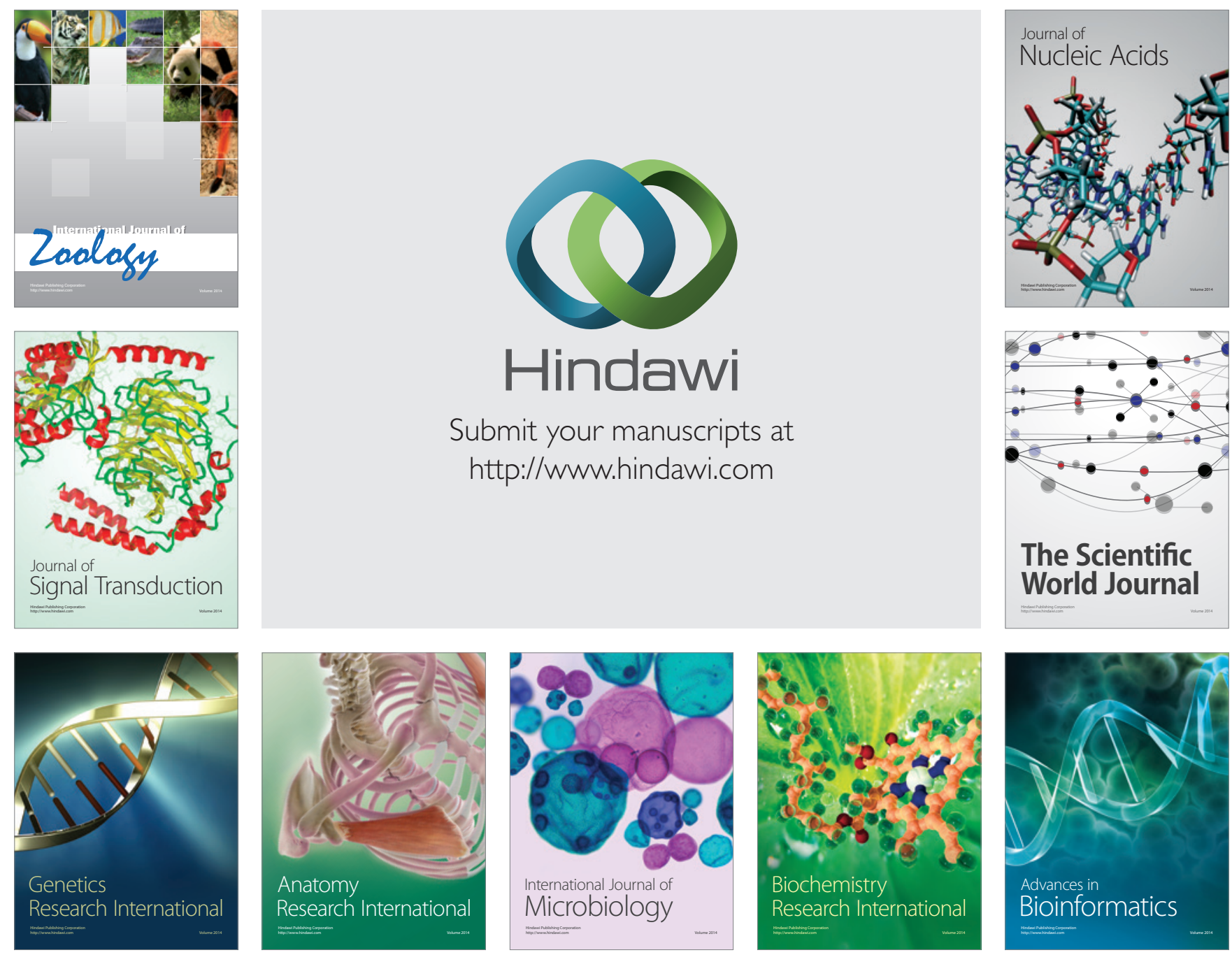

The Scientific World Journal
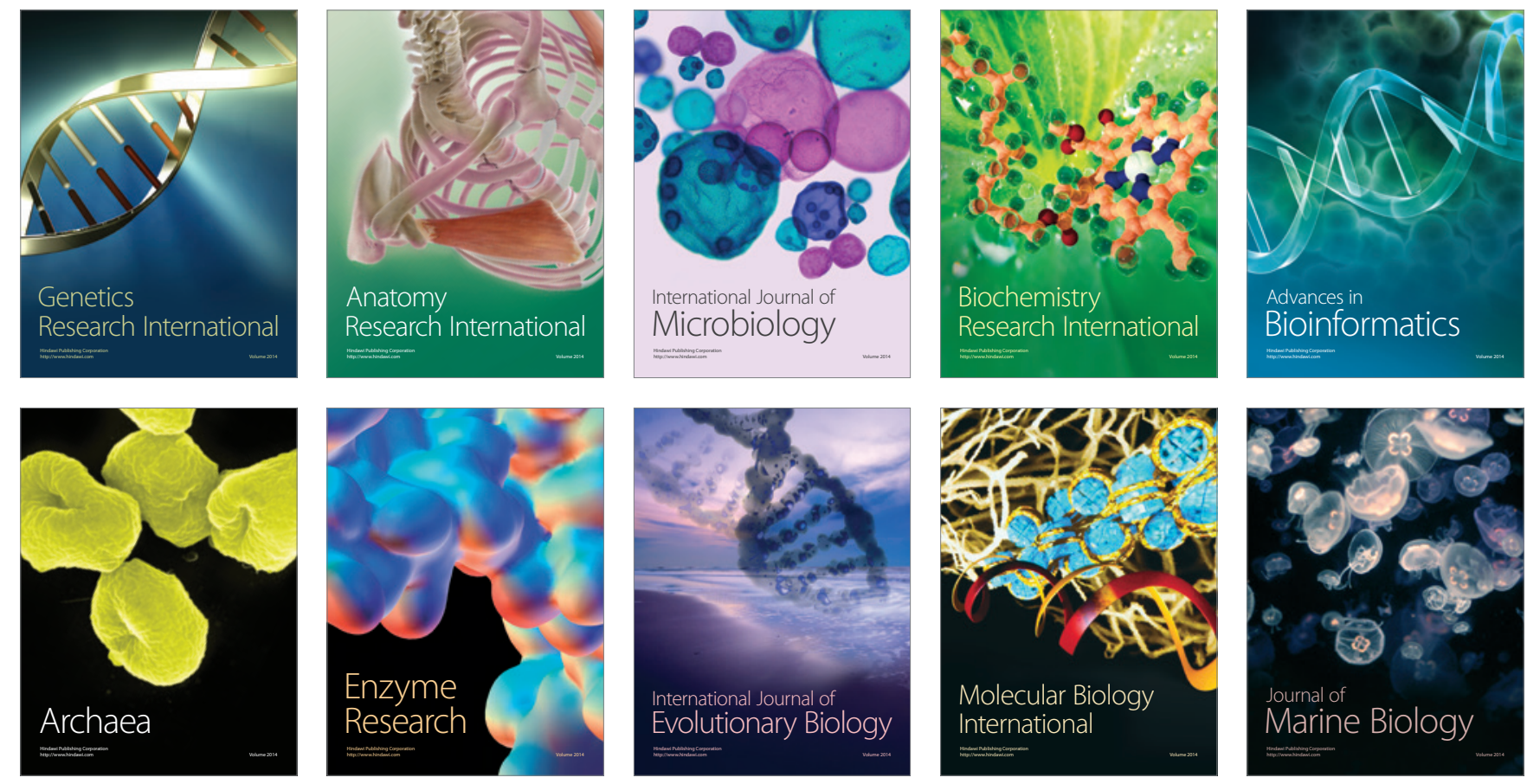